\section{実験 結 果}

Copper-8-quinolinolate をそれぞれ 0，0.5，1.0\% ずつ添加 した実験結果は第 2〜5 表の如くである

以上第 2〜5 表までの結果についてつぎのことがいえる。

1. 同一試料，同一菌種でPetri 皿 3 個の試験を行ったが， 注 とんど同様な発育状況を示した。

2. いずれの菌株にあっても，いずれの淮料試料に刘しても防 徽凧無添加の場合には 3 日ごろより明らかに菌の繁殖が認められ 時間の経過に之もない塗料陚料全体に侵害が行われる。

3. $0.5 \%$ の添加では Penicillium (P-4 号菌) に対して相当 の防徽效果を示したが，他の 3 種の菌洙に対してはまだ十分とは いえない。

4. $1.0 \%$ の添加により Penicillium（P-4 号菌）に対しすべ ての浲料試料において相当強力に効果を示し，他の 3 種に対して
も落料組成の如何により十分効果を示すことがみられた。しかし 敕料組成との関連に関しては後報によることとして,ここではこ とさらに言及しないこととする。

\section{要 約}

組成を異にする 19 種類のベイント類に対し Copper-8-quinolinolateを $0,0.5,1.0 \%$ ずつ添加混入して染装部分より分離し た 4 種の糸状菌種の侵㕩力に対する抗力を武験した。その $1.0 \%$ 添加でも完全に侵害性を阻止しえないが P-2 号菌 (Asp. niger), P-4 号菌 (Penicillium sp.) に対しては相当すぐれてた效果を示し たが，R-2 号菌 (Rhizopus nigricans), 拉よび P-1号菌 (Mucor hiemalis）に対しては湦料組成にも関連するが， $1.0 \%$ 添加でも 十分防微力を発揮できなかった。

（昭和 29 年 4 月 4 日，日化第 7 年会講演）

（東京大学工学部応用化学科：東京都交京区）（昭和 29 年 5 月 25 日受理）

\title{
（297）イオン交換樹脂に関する研究（第了報）* 重金属吸着用アニオン交換樹脂の秧造
}

\author{
桑 田 勉・吉川貞 雄・窪 寺 忠 良
}

\section{1. 緒霉}

脂肪族アミノ基を有するアニオン交換樹脂に，重金属イオンの 吸着現象が見られることは，すでにイオン交換樹脂発達の初期の 特許 1 (13) に記載され，また Sussman ${ }^{3)}$ はアニオン交換樹脂が銅 イオンや，銅アンモニア錯イオンを吸着することを記している。

著者らはメラミン・ホルムアルデヒド采のアニオン交換樹脂の 製造実験中に，この系統の樹脂の中に，その OH 形樹脂を用いる と, 市販アニオン交換樹脂に比し, 著しく多くの重金属イオンを 吸着する樹脂のあることを発見したので，その種樹脂の製造方法 ならびにそれに関する二, 三の考察につき報告する。

樹脂の製造は，イオン交換樹脂母体としてのメラミン・ホルム アルデヒド粒子の製造と，Mannich 反応によるこの母体への脂 肪族アミノ基の導入の 2 段階に分けて行った。

\section{2. 粒状メラミン・ホルムアルデヒド榯脂の製造}

メラミンとホルマリンとをアルカリ性で蹜合させると，酸性の 場合よりる反応が徐々に進行し, 反応液は次第に白濁しつつ, 水 相と分離し，さらに反応をつづ汁ると，水に不溶性の白色樹脂を 生成する。この反応過程に生成する乳状物は, 水よりるホルムア ルデヒドにとけ易いため, 水とホルムアルデヒドの比を適当に調

*) 第 2 報は工化 55, 625 (1952).

1) 1. G. Farbenind, A.-G. 日本特許 133, 985(Feb. 22, 1940).

2) 同上, 日本特許 133,685 .

3) F. C. Nachod, "Ion Exchange" p. 245, Acad. Press Inc., New York (1949).
節することによって乳状物の析出速度を増減することがでさる。 したがって，この析出時に適当な撜拌を与えることによって，適 当な粒度のメラミン・ホルムアルデヒド粒子を製造することがで きる。なお，このような方法やによるこの種樹脂の製法は，これ までに知られていない。

\section{実 唤}

三つロフラスコ中にメラミン, $37 \%$ ホルムアルデヒド水溶液, 水を第 1 表所定の割合で入れ, 還流冷却器, 温度計を㨉入し, 気

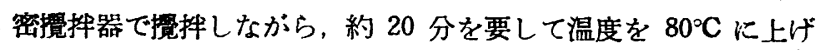

第 1 表 メラミン・ホルムアルデヒド樹脂粒子の製造

配 合割合

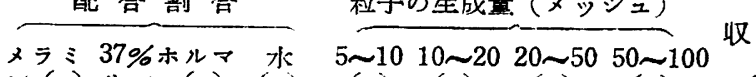

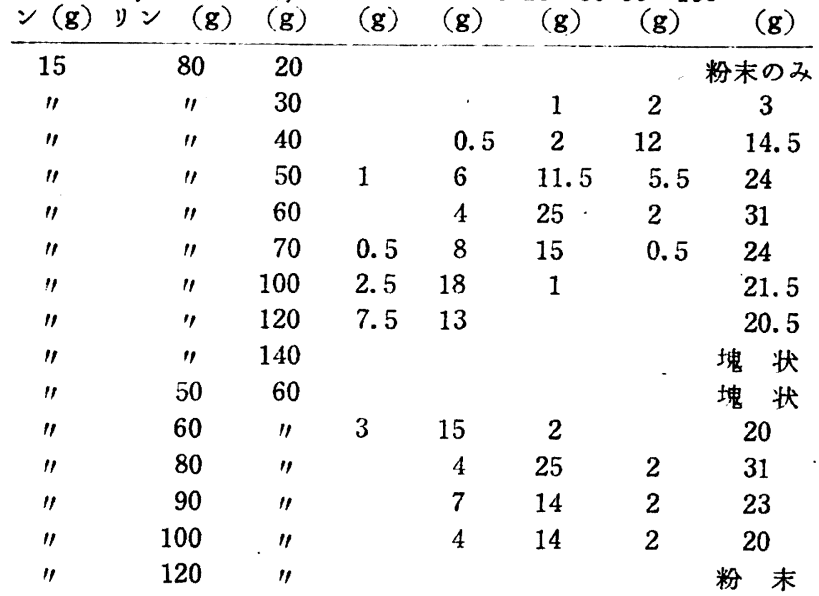

4）聚田，吉川，日本特許公告 3,141 (Jul. 3, 1953). 
ると,メラミンは溶解して液は透明となる。ここへ $1 \mathrm{~N}$ 菏性ソー ダ水溶液 $10 \mathrm{cc}$ を加え，アルカリ性とし，80 85 ${ }^{\circ} \mathrm{C}$ で毎分 150 ２00 回転の速さで撜找し，6時間反応させる。反応途上 $1.5 \sim$ 3 時間で白色の乳状物を生ずるが，加えた水の量が多いるのほど 白濁までの時間が短い。反応後生成した樹脂粒子は液相と分離後 水洗し，100 $105^{\circ} \mathrm{C}$ で 8 時間乾燥した後，篩別し科量した。第 1 表の中, 収量とは 5〜100 メッシュの粒子の重量の総和で, こ れより大きいもの，小さいものは，イオン交換樹脂製造の母体と しては不適当であるから除いた。

\section{結 果}

この反応において樹脂粒子の大きさが，水とホルマリンの比に よって大きく支配されるのは興味あるこ一である。すなわちホル マリンの量が一定の場合に, 水の量が少ないと粉末状のメラミン 樹脂のみしか得られないが，水量の増加につれて，次第に樹脂粒 子は大きくなり，最後には一つの塊となってしま5。また水の量 を一定にしてホルマリンの量を変えた場合には，ホルマリンの量 が堌加して水とホルマリンの比が小さくなると，樹脂粒子は次第 に小さくなり粉末状となる。この場合にも塊状から粉末までの段 階的な変化が見られる。すなわち水の量が多いと，メラミン・ホ ルムアルデヒド樹脂の中間物が液相中に溶解し難くなり, 反応の 進行とともに，急激に析出し，この程度の㩭䢁では適当な粒子に 分散させることが不可能となり，樹脂は一つの塊になってしま う。また水に比してホルマリンの量が多くなると, 析出が極めて 徐々に行われ，樹脂が微粉末となる。

イオン交換樹脂製造の母体としては，20〜50メッシュの大きさ が適当であるので，この大きさの粒子の収率の最す良好なメラミ ン $15 \mathrm{~g}, 37 \%$ ホルマリン $80 \mathrm{~g}$ ，水 $60 \mathrm{~g}$ の配合で製造したもの を以下の実験に用いた。な後でも述べるように，この樹脂は重 金属イオンを吸着する性質を示さない。

\section{3. 粒状メラミン・ホルムアルデヒド榯 脂への脂肪族アミノ基の学入}

上記のメラミン・ホルムアルデヒド樹脂に，メチルアミンのよ うな脂肪族アミンの塩酸塩とホルマリンを酸性で反応させると, いわゆる "Mannich 反応”によって

$$
\begin{aligned}
& \mathrm{R}-\mathrm{NH}_{2}+\mathrm{CH}_{2} \mathrm{O}+\mathrm{CH}_{2} \mathrm{NH}_{2} \cdot \mathrm{HCl} \stackrel{\mathrm{H}+}{\longrightarrow} \\
& \mathrm{R}-\mathrm{NH}-\mathrm{CH}_{2}-\mathrm{NH}\left(\mathrm{CH}_{3}\right) \cdot \mathrm{HCl}+\mathrm{H}_{2} \mathrm{O}
\end{aligned}
$$

メラミン樹脂のアミノ基にメチレンアミノ基が導入され， $\mathrm{OH}$ 形 樹脂が重金属イオンをよく吸着するよ5になる。

\section{実}

樹脂の製造：第 2 表の如く，メラミン樹脂粒，37\% ホルマリ ン,フミンの塩酸塩を所定量配合し，これに所定の酸を触媒とし て添加し，80 $85^{\circ} \mathrm{C}$ で 1 時間反忍させた後, 樹脂粒を液相より 分離し, 水洗後, 風乾し, つぎの方法で銅イオンの吸着量を測定 した。

銅吸着量の測定： 約 $1 \mathrm{~g}$ の樹脂を $1 \mathrm{~N}-\mathrm{NaOH} 50 \mathrm{cc}$ 中に 2 回浸漬した後，さらに $50 \mathrm{cc}$ の $1 \mathrm{~N}-\mathrm{NaOH} に 一$ 夜浸清して，樹 脂を $\mathrm{OH}$ 形に再生する。その後フェノールフタレインで水洗液が アルカリ性を示さなくなるまで, 蒸溜水で水洗し, $0.5 \mathrm{M}$ 硫酸銅 水溶液 $50 \mathrm{cc}$ に一夜漫漬する。翼日，洗液に銅イオンを認めなく なるまで水洗し， $1 \mathrm{~N}-\mathrm{HCl} 25 \mathrm{cc}$ で銅の溶離を行い，溶離した銅 イオン准 $0.1 \mathrm{~N}$ シアン化カリ溶液で滴定し，同時に供試樹脂を
$100 \sim 105^{\circ} \mathrm{C}$ で恒量となるまで（約 3 時間を要する）乾燥した後, 精稏して樹脂 $1 \mathrm{~g}$ 当りの銅吸着量を求めた。

第 2 表 メラミン樹脂粒子の後处理による脂肪

\begin{tabular}{|c|c|c|c|c|c|c|c|c|c|}
\hline \multirow{3}{*}{ 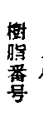 } & \multirow{3}{*}{ 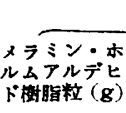 } & \multirow{3}{*}{ 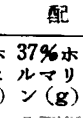 } & & 合 & 制 & 合 & \multirow[b]{2}{*}{ 媒 } & \multirow{3}{*}{$\begin{array}{l}\text { 銅吸誉 } \\
\text { 能力 } \\
\left(\frac{\mathrm{m} \cdot \mathbf{M}}{\mathrm{g}}\right)\end{array}$} & \multirow{3}{*}{ 绩 } \\
\hline & & & & $\nabla \Sigma$ & ン & 触 & & & \\
\hline & & & 䅜 & 数 & n $(g$ & ) 種 & 到) & & \\
\hline 1 & 10 & 30 & & $\mathrm{NH}_{4} \mathrm{Cl}$ & 20 & な & L & 0.23 & 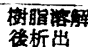 \\
\hline 2 & " & " & & " & 25 & $\begin{array}{c}10 \% \mathrm{HCl} \\
\text { 水 }\end{array}$ & $\begin{array}{r}5 \\
10\end{array}$ & 0.34 & $n$ \\
\hline 3 & $"$ & $"$ & & $"$ & 15 & $10 \% \mathrm{HCl}$ & 2 & 1.31 & " \\
\hline 4 & " & " & • & $"$ & 25 & " & 5 & 1.36 & $"$ \\
\hline 5 & " & $"$ & & $"$ & $" \prime$ & $"$ & 10 & 1.87 & $"$ \\
\hline 6 & $"$ & 10 & $\mathrm{CH}_{5}$ & $s \cdot \mathrm{NH}_{2} \cdot \mathrm{HC}$ & $\mathrm{Cl} 6$ & " & 5 & 0.65 & \\
\hline 7 & $"$ & 30 & & $"$ & 20 & " & 10 & 1.31 & \\
\hline 8 & $"$ & $"$ & & $"$ & " & $10 \% \mathrm{H}_{3} \mathrm{SO}_{4}$ & $" \prime$ & 1.42 & \\
\hline 9 & $"$ & $\pi(C$ & & 3) ${ }_{2} \mathrm{NH} \cdot \mathrm{HC}$ & $\mathrm{Cl} 25$ & な & ᄂ & 0.06 & \\
\hline 10 & $"$ & $"$ & & $"$ & 20 & $10 \% \mathrm{HCl}$ & 2 & 0.83 & \\
\hline 11 & $"$ & , & & $n$ & 25 & $n$ & 10 & 1.09 & \\
\hline 12 & $"$ & $"$ & & $n$ & $"$ & $10 \% \mathrm{H}_{2} \mathrm{SO}_{4}$ & $" \prime$ & 1.17 & \\
\hline & & xラ & シン・ & ホルムフル & レデヒト & 樹脂 & & 0.00 & \\
\hline
\end{tabular}
族アミノ基の導入反応

\section{結果}

触媒として用いた酸の量の多いものほど, 脂肪族アミノ基が多 く導入され，銅の吸着量が大きい。また酸の中では，硫酸を用い たものの方が，塩酸を用いたものより同一濃度において良好な結 果を示している。アミンとして塩化アンモンを用いると，樹脂母 体がいったん溶解してから, 再び析出するため, 能力は大きいが 樹脂が脆い。結局アミンとしてはメチルアミン, 触媒としては硫 酸を用いたものが最良の結果を示す。

第 3 表に本実豎において製造した樹脂と市販樹脂の能力を示 す。表中において, 酸吸着能とはイオン交換に関与する全アミノ 基の $\mathrm{mM}$ 数を, 強塩基能とは, 樹脂の $\mathrm{OH}$ 形に $\mathrm{NaCl}$ を加え た時, 液中に交換によって生成する $\mathrm{NaOH} の \mathrm{mM}$ 数であり， いずれる測定は R. Kunin と R. J. Myers の方法(5)にしたが った。

\begin{tabular}{|c|c|c|c|c|}
\hline 樹脂の種類 & $\begin{array}{l}\text { 銅吸着能(a) } \\
(\mathrm{mM} / \mathbf{g})\end{array}$ & $\begin{array}{l}\text { 酸吸着能 } \\
(\mathrm{mM} / \mathbf{g})\end{array}$ & 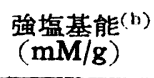 & $\begin{array}{c}\mathbf{a} / \mathbf{b} \times 100 \\
(\%)\end{array}$ \\
\hline $\begin{array}{l}\text { No. } 7 \text { (メチルア } \\
\text { ミンン处理) }\end{array}$ & 1.31 & 3.94 & 0.53 & 33.2 \\
\hline $\begin{array}{c}\text { No. } 5 \text { (塩化アン } \\
\text { モン处理) }\end{array}$ & 1.87 & 4.76 & 0.05 & 39.3 \\
\hline $\begin{array}{c}\text { No. } 4 \text { (塩化アン } \\
\text { モ处理) }\end{array}$ & 1.36 & 4.15 & 0.03 & 32.8 \\
\hline $\begin{array}{l}\text { メラミン・ホルム } \\
\text { アルデヒド樹脂 }\end{array}$ & 0.00 & 4.25 & 0.00 & 0 \\
\hline $\begin{array}{l}\text { メタフェニレンジ } \\
\text { アミシ・ホルム } \\
\text { アルデヒド樹脂 }\end{array}$ & 0.00 & 3.37 & 0.13 & 0 \\
\hline Amberlite IR-4 B & 0.81 & 7.42 & 0.52 & 10.9 \\
\hline
\end{tabular}

第 3 表 樹脂能力の比较

第 3 表からわかるよ5に，樹脂の通例のイオン交换能力と銅の 吸着量との間には平行関係は認められない。すなわち苊香族了ミ ン系のメラミン・ホルムアルデヒド, メタフェニレンジアミン・ ホルムアルデヒド樹脂は銅をまったく吸着しない。Sussman ${ }^{3} は$ 硫酸銅の水溶液をある種のアニオン交換樹脂の Cl 形に通ずると 銅が吸着されることを見出し，次式において，生成した

$$
\mathrm{Cu}^{2+}+2(\mathrm{RNH}) \cdot \mathrm{Cl} \longrightarrow\left(\mathrm{Cu}(\mathrm{RN})_{2}\right) \mathrm{Cl}_{2}+2 \mathrm{H}^{+}
$$$$
\text { ( } \mathrm{R} \text { はアニオン交換樹脂母体) }
$$

5) "Ion Exchange Resin" p. 152 (John Wiley \& Sons. Inc., New York, 1950). 
$\mathrm{H}^{+}$と吸着された $\mathrm{Cu}^{2+}$ のモル比から, ジアンミンとして銅が吸 着されたものと考え, さらにこれらの $\mathrm{Cu}^{2}+$ の吸着量がアニオン 交換澍脂の交換能力の $20 \%$ にすぎないことから，立体的にジア ンミン錯生成に適するように配置されたアミノ基のみが銅の吸着 に関与するものと考えている。

第 3 表に揭げた Amberlite IR-4 B は著者らの試製した樹脂に 比して交換に関与するアミノ基の数も多く, 強塩基能は䚾とんど 変わりないのにもかかわらず, 銅の吸着量は劣っている。このこ とは立体的にジアンミン以上の錯生成に適するよ5な立体的配置 を有するアミノ基でないと, 重金属の吸着には適しないことを示 している。また塩化アンモンと反応させたアミノ基は，メチルア ミンを反応させた場合より，導入されたアミノ基が低級で塩基性 が弱いにもかかわらず, 銅吸着能と酸除去能の比が両者ほぼ相等 しいのはアミノ基の塩基性の強さより,アミノ基の立体配置が重 要であることを示している。今, ジァンミンとして銅が吸着され たものとすれば，本試製樹脂のアミノ基の中，65〜 75\%が銅吸着 に関与していることとなる。恐らく本試製樹脂ではメラミンのア ミノ基に対し<smiles>N=C(CN)CN</smiles>

の如く脂肪族アミンが導入され，ポリエチンンポリアミンを主体
とする Amberlite IR-4 B より，アミノ基が立体的に近接した状 態で存在するのではあるまいか。そうとすれば，重金属吸着の目 的に適するアニオン交換樹脂には，本法による如き特別な製法を 用いねばならないこととなる。また Amberlite IRA 400 の如

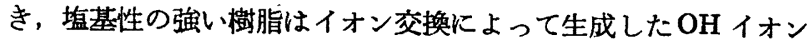
が, 液相中で重金属イオンと反応して水酸化物の沈澱を形成する ため，金属吸着の目的には不適当である。

なお次報において，本樹脂を用いた応用例として，鉄、ニッヶ ルの分離を報告する。

\section{4. 総 括}

重金属カチオン吸着用アニオン交換樹脂の製造実験を行い,つ ぎの事柄を見出した。

1. 水溶液中でメラミン・ホルムアルデヒド樹脂の製造を行 場合, アルカリ性で樎合反応を行わせる際に，加える水の量の増 減によって生成樹脂の粒度を調節しうる。

2. メラミン樹脂に Mannich 反応による脂肪族アミンの導入 を行った樹脂は，従来のアニオン交換樹脂に比し，重金属の吸着 量が大きい。

（昭和 27 年 4 月，日化第 5 年会諈演） 本研究の費用は文部省科学研究費によった。

（日本電信電話公社電気通信研究所：東京都武藏野市）（昭和 29 年 5 月 25 日受理）

（298～299）共重合に関する研究（第6７報）*

久保内良・山本連・園靖之助・松尾博

\section{（第 6 報）塩化ビニルとアクリル酸メチル 共重合物の再沈澱について}

\section{（久保内良齐・山本連・園 靖之助）}

\section{I. 緒 费}

共重合反応に関する実験において正しい結果をうるためには, 共重合物を末反応単量体および溶媒等から定量的に分離すること がとくに必要である。共重合に関してこれまで報告されている研 究には，再沈澱の全然行われていない報告す相当に多いが，共重 合物を定量的に分離するためには，適当な溶媒一非溶媒系を使っ てくり返し再沈没を行うことや，とくに共重合物がベンゼンに溶 解する場合には，以わゆるベンゼン凍結法 (frozen benzene

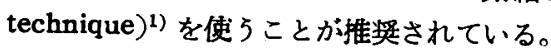

われわれは,さきに塩化ビニル (V. C. ) とアクリル酸メチル (M.A.)の塊状および溶液共重合について央験し, 単量体の相対 反応性 $\boldsymbol{r}_{1}, \boldsymbol{r}_{2}$ が共重合の進行にともなって変動する現象の認め られることを報告したが2)，いずれの場合にも共重合生成物をメ

*) 第 5 報は工化 57,390 (1954).

1) F. M. Lewis, F. R. Mayo, Ind. Eng. Chem. Anal. Ed. 17, 134 (1945).

2）塊状共重合の報告は久保内, 山本, 園, 工化 57,316(1954); 湶液共重合の報告は工化 57,386 (1954).

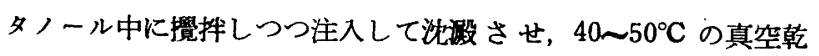
燥器中で恒量になるまで真空乾燥させたたけで，これをさらにく り返し再沈渐する操作は行わなかった。今回は前記報告中の二, 三の試料についてアセトンーメタノールおよびアセトンーヘキサン 采による再沈澱の影響を検討した。E. C. Chapin ら3)は V.C. と M. A. の塊状共重合に関する報告に拈いて，V.C. の割合の 多い場合には，共重合生成物をエタノール中に注入して沈澉させ ているが, M.A.の割合の多い場合には, へキサン中に注入して 沏殿させているので，この二つの場合について再沈澱を行ってみ た。この共重合物はベンゼンに溶解しないので, ベンゼン倲結法 を試みることはできなかった。

\section{II. アセトンーメタノール柔による再沈澱}

使用した試料はV.C. と M.A.の仕込及の割合が $10: 90$ で, $50^{\circ} \mathrm{C}$ において溶液共重合（溶媒, アセトン)させたものである。 これを精製したアセトンに溶解し，メタノール中に摫䢁しつつ注 入し，共重合物を再沈波させ，茜過後メタノールで洗浄し，真空 乾燥器中で乾嬠した。このようにして乾燥した共重合物の重量 を，仕込みの単量体混合物の重量に対するパーセントで胃わした ものを再沈激後の重合率とした。この試料について前報と同じ塩 素分析法によってその塩素含有率を測定した結果は第 1 表のとお

3) E. C. Chapin, G. E. Ham, R. G. Fordyce, J. Am. Chem. Soc. 70, 538 (1948). 